\title{
Induced Abortion and Unintended Pregnancy In Guatemala
}

By Susheela Singh, Elena Prada and Edgar Kestler

Susheela Singh is vice president for research, Guttmacher Institute,

New York; Elena

Prada is an independent consultant, based in Bogotá, Colombia; Edgar Kestler is director, Epidemiological Research Center in Sexual and Reproductive Health (CIESAR),

Guatemala City, Guatemala.
CONTEXT: Although Guatemalan law permits induced abortion only to save a woman's life, many women obtain abortions, often under unsafe conditions and in response to an unintended pregnancy. Recent studies indicate that unsafe abortion is a key factor contributing to maternal morbidity and mortality in the country, but no national data on the incidence of abortion exist.

METHODS: Surveys of all hospitals that treat women for postabortion complications and of 74 professionals who are knowledgeable about the conditions of abortion provision in Guatemala were conducted in 2003. Indirect estimation techniques were used to calculate the number of induced abortions performed annually. Abortion rates and ratios and the level of unintended pregnancy were calculated for the nation and its eight regions.

RESULTS: Nearly 65,000 induced abortions are performed annually in Guatemala, and about 21,600 women are hospitalized for treatment of complications. Abortions occur at a rate of 24 per 1,000 women aged 15-49, and there is one abortion for every six births. The abortion rate is higher than average in the Southwest (less developed, mainly indigenous population) and Metropolitan (more developed, mainly nonindigenous population) regions (29-30 per 1,000 women). Over a quarter of all births are unplanned; combining unplanned births with abortions yields estimates that $32 \%$ of pregnancies in Guatemala are unintended, with an unintended pregnancy rate of 66 per 1,000 women.

CONCLUSIONS: Unsafe abortion has a significant impact on women's health in Guatemala. Comprehensive government programs are needed to address the issues of unintended pregnancy and unsafe abortion, with attention to regional differences.

International Family Planning Perspectives, 2006, 32(3):136-145
Unsafe abortion is a leading cause of reproductive morbidity and mortality in countries where abortion is illegal or severely restricted, as is the case in Guatemala. * In these settings, abortion is a clandestine event that is poorly documented and difficult to study. Little empirical research on abortion has been conducted in Guatemala, and no nationallevel data on abortion incidence are available. As a result, there is limited public awareness of the issue of unsafe abortion, its consequences for women's health or its impact on the health care system.

In Guatemala, abortion is against the law except to save a woman's life. ${ }^{1}$ Nonetheless, the little evidence that is available suggests that induced abortion is common. Much of this evidence is based on women hospitalized for treatment of abortion complications. However, Ministry of Health reports of the number of women treated for abortion complications in all hospitals are acknowledged to be undercounts. ${ }^{2}$ A large-scale surveillance initiative, part of the Postabortion Care Program of the Epidemiological Research Center in Sexual and Reproductive Health (CIESAR), re-

*Unsafe abortion is defined as a procedure for terminating pregnancy either by persons lacking the necessary skills or in an environment lacking the minimal medical standards, or both (source: World Health Organization (WHO), The Prevention and Management of Unsafe Abortion, Geneva: WHO, 1992). ported that 13,928 incomplete abortions were treated in 22 public hospitals between July 2003 and December 2004. ${ }^{3}$ Other hospital-based studies further support the conclusion that induced abortion is common. One study of abortion patients treated in six hospitals between August 1993 and July 1994 found that about 50\% were likely to have had induced abortions ${ }^{4}$; a 1995 Ministry of Health study found that $76 \%$ of abortion patients in seven hospitals had had a previous abortion..$^{5}$ Treatment of abortion complications results in substantial costs to hospitals: In a study conducted over five months in 2000 at a Coatepeque hospital, $30 \%$ of the maternity budget and $10 \%$ of the total hospital budget were spent treating abortion complications. ${ }^{6}$

According to a recent government study on maternal mortality, abortion is the third most important cause of maternal deaths. ${ }^{7}$ A four-year surveillance program carried out in the Guatemala City metropolitan area found that between 1993 and 1996, 110 of 435 maternal deaths were due to infection, and 34 of these were related to induced or spontaneous abortion. ${ }^{8}$ The study did not provide a breakdown by type of abortion, but it is likely that induced abortion was a key factor.

In Guatemala, as in other countries, women may resort to abortion when they have an unintended pregnancy. Some are unable to care for a child; some already have all the chil- 
dren they want; others do not want the pregnancy because it is the result of forced sex or incest; and some women's lives or health are at risk if they continue with the pregnancy. A number of other factors also contribute to unintended pregnancy and abortion, including insufficient and inaccurate information about contraception, inadequate access to services and supplies, and incorrect and inconsistent contraceptive use. Survey data from 2002 showed that, on average, actual family size was 4.4 but the desired size was 3.7 , and that $28 \%$ of all recent births were unplanned, a level similar to the $29 \%$ estimated for Latin America. ${ }^{9}$ Although overall contraceptive use increased from $23 \%$ in 1987 to $43 \%$ in $2002,{ }^{10}$ this is still substantially lower than use in the region as a whole (71\%). ${ }^{11}$ In addition, between 1987 and 2002, the unmet need for contraception among currently married Guatemalan women grew from 19\% to 28\%.

The government of Guatemala has recently enacted policies and plans to improve women's reproductive health, but no studies have assessed their impact. ${ }^{12}$ However, the issue of maternal death and illness resulting from unsafe abortion has not been properly addressed, and the lack of comprehensive and reliable data makes effective action difficult. Because unsafe abortion is a critical factor in maternal morbidity and mortality in Guatemala, and because it represents a significant cost for meager hospital budgets, quantitative indicators are needed to assess the extent of the practice, how it affects women's health and how reproductive health services, including postabortion care, could be improved.

In this article, we apply an established indirect estimation methodology and draw on new data collected from health facilities and health professionals to generate estimates for the basic indicators of unsafe abortion in Guatemala-the number of women hospitalized each year for the treatment of complications following unsafe induced abortions, and national and regional estimates of the incidence of induced abortion. In addition, we combine these abortion data with survey and other data on the planning status of births to obtain estimates of the rate of unintended pregnancy among Guatemalan women.

\section{DATA AND METHODS}

\section{Data Sources}

The key data sources for the estimates of abortion incidence were two surveys designed and fielded for this study-a survey of hospitals that treat postabortion patients and a survey of knowledgeable key informants. The study design and protocols were based on prior research that developed a methodology for estimating abortion incidence, and were adapted to the Guatemalan situation. ${ }^{13}$ Questionnaires for both surveys were pretested in early September 2003; the surveys were fielded from late September through October 2003. Details of the study design and fieldwork are described below.

Other data sources included the 1995 Demographic and Health Survey (DHS) and the 2002 Guatemala National Survey of Maternal and Child Health (ENSMI), which pro- vide information on contraceptive use, planning status of births and unmet need for contraception. Sample sizes were 12,403 and 9,155 women aged 15-49 for the DHS and ENSMI, respectively. Although the 1995 survey did not include the Petén region, both surveys were based on nationally representative samples.*

- Health Facilities Survey. An inventory of hospitals was drawn from Ministry of Health lists and telephone directories; this list was updated during fieldwork with information provided by respondents. A total of 225 hospitals were initially identified. Of these, 42 were eliminated; 23 did not provide treatment for abortion complications, 13 did not exist at the time fieldwork was carried out and six were listed twice. Because the number of hospitals that provide postabortion care in Guatemala is relatively small, all 183 of the eligible hospitals-127 private and 56 public facilities-were surveyed. Public facilities are those operated by any branch of government, and include hospitals that are part of the Social Security system.

The respondent for each hospital was the senior professional deemed the most knowledgeable about the postabortion care provided at the facility, and was typically the chief of the obstetrics and gynecology department or an obstetrician-gynecologist. In five cases, we interviewed the next most senior professional. We completed interviews for 178 hospitals; of the five missing cases (all of which were private facilities), two respondents did not complete the interview and three refused to be interviewed, resulting in an overall response rate of $97 \%$. The response rate was $96 \%$ for private hospitals and $100 \%$ for public hospitals.

The Health Facilities Survey provided estimates of the number of women treated for postabortion complications. Respondents were asked a series of questions, including: whether treatment of abortion complications is provided in an outpatient or inpatient setting, or both; and for the categories that apply, the total number of postabortion patients (spontaneous and induced) treated as outpatients and inpatients in the average month and in the past month. Specifying these two time frames increased the likelihood of accurate recall and of capturing variation from month to month. These two numbers were averaged and multiplied by 12 to produce an estimate for the calendar year. This information formed the basis for estimating the incidence of abortion using an indirect estimation methodology, described below.

- Health Professionals Survey. On the basis of information gathered from program planners and other stakeholders, the research team prepared a list of health professionals who were known to be familiar with postabortion services, covering all sectors and a wide range of professions, including clinicians, policymakers, researchers and women's activists. A purposive sample of 85 professionals was selected, and 74 were successfully interviewed. These professionals came from 21 of the 22 departments of Guatemala

*Petén is home to only 3\% of the total population, suggesting that its exclusion from the 1995 DHS did not significantly affect the representativeness of the survey. 


\begin{tabular}{|c|c|c|c|c|c|}
\hline Region & $\begin{array}{l}\text { No. treated } \\
\text { for abortion } \\
\text { complications* }\end{array}$ & $\begin{array}{l}\text { No. of live } \\
\text { births }\end{array}$ & $\begin{array}{l}\text { No. of } \\
\text { miscarriagest }\end{array}$ & $\begin{array}{l}\text { No. treated for } \\
\text { miscarriages }\end{array}$ & $\begin{array}{l}\text { No. treated } \\
\text { for induced } \\
\text { abortion } \\
\text { complications§ }\end{array}$ \\
\hline Total & 27,014 & 405,017 & 13,811 & 5,389 & 21,625 \\
\hline Metropolitan & 8,844 & 74,373 & 2,536 & 1,823 & 7,021 \\
\hline North & 1,014 & 47,200 & 1,610 & 409 & 605 \\
\hline Northeast & 2,237 & 35,469 & 1,209 & 514 & 1,723 \\
\hline Southeast & 2,040 & 30,634 & 1,045 & 348 & 1,692 \\
\hline Central & 3,000 & 41,537 & 1,416 & 670 & 2,330 \\
\hline Southwest & 7,112 & 100,899 & 3,441 & 1,056 & 6,056 \\
\hline Northwest & 2,058 & 59,553 & 2,031 & 408 & 1,650 \\
\hline Petén & 709 & 15,352 & 524 & 161 & 548 \\
\hline
\end{tabular}

*Includes both spontaneous and induced abortions. †Miscarriages at 13-22 weeks' gestation, calculated as $3.41 \%$ of all live births. $\neq$ Calculation assumes that the proportion of women with miscarriages who obtain treatment is the same as the proportion of women who deliver in hospitals. §The total number treated for any abortion complication minus the number treated for complications of spontaneous abortions. Sources: No. treated for abortion complications-Health Facilities Survey. No. of live births-based on age-specific fertility rates from the $2002 \mathrm{ENSMI}$ and the number of women in each five-year age-group according to 2002 census data. Proportion of women who deliver in hospitals—based on the 2002 ENSMI.

(Petén, the most remote and difficult to reach, was not represented in the survey). The majority were working in urban areas, but an effort was made to include professionals who were familiar with the conditions related to abortion in rural areas and among indigenous women. Of the entire group, $30 \%$ had worked in rural areas for six months or longer and about one in seven worked primarily in rural areas; $51 \%$ felt they were knowledgeable about both indigenous and nonindigenous populations ( $7 \%$ felt knowledgeable about only the indigenous and $42 \%$ about only the nonindigenous population).

The Health Professionals Survey was designed to elicit the perceptions of knowledgeable key informants on various aspects of induced abortion in Guatemala. This survey provided the necessary information to calculate the "multiplier" factor, which is used to adjust the estimate of the number of women who have induced abortions to include those who experience no complications, those who do not seek medical care or do not obtain treatment in a formal medical facility, and those who die as a result of the abortion. The multiplier is based on a series of questions: the distribution of all women seeking abortion, according to type of provider; the probability that women would experience complications requiring medical care, according to type of provider; and the probability that women who have a complication will receive medical care from a health facility.

- Data collection. CIESAR organized and conducted the fieldwork for both surveys. The fieldwork staff consisted of 15 female physicians-three regional coordinators and 12 interviewers. Women were chosen to field the survey because they are believed to be better interviewers on abortion and to have better knowledge about unsafe abortion than men.

*Although some women who experience spontaneous pregnancy loss at 12 or fewer weeks of gestation may seek medical care, many are likely to do so on an outpatient basis, and so relatively few will be hospitalized. Pregnancy losses at 23 or more weeks are not considered because they are usually classified as fetal deaths rather than spontaneous abortions.
Health professionals were chosen as interviewers because respondents are more willing to talk about abortion with their colleagues than with persons outside the profession. ${ }^{14}$

Field staff were organized into five teams. One regional coordinator managed the team for the Metropolitan region, which included four interviewers; the other two coordinators were each in charge of two teams, each of which consisted of two interviewers. In August 2003, all fieldwork personnel attended a three-day training workshop to become familiar with the study, the questionnaires and the instructions for implementing the fieldwork.

- Adjustment for nonresponse. Because we included the universe of all health facilities that provide postabortion care in Guatemala, the only weighting necessary was a minor adjustment to compensate for nonresponse. The weighting factor used for nonrespondents was the inverse of the ratio between the actual and expected number of interviews. Weighting factors for private hospitals were 1.012 for the Metropolitan region, 1.068 for the Central and Northeast regions, 1.105 for the Southwest and 1.052 for the Petén; factors for other regions were 1.000. Weights were applied to the data from interviewed health facilities to obtain estimates for the total of 183 facilities nationwide.

\section{Estimating the Incidence of Induced Abortion}

Following an approach used in prior studies, ${ }^{15}$ we calculated the incidence of induced abortion by first estimating the annual number of women receiving treatment for abortion complications and then applying the multiplier, or inflation factor, that represents the proportion of women having an abortion who do not need treatment or do not obtain it at a health facility.

-Women treated for abortion complications. Using data from the Health Facilities Survey, we estimated that 27,014 Guatemalan women were treated for complications of spontaneous or induced abortion in 2003 (Table 1). Because complications of induced and spontaneous abortion often are similar, and because legal restrictions on induced abortion may lead to underreporting, it is difficult to correctly categorize postabortion cases according to the cause of pregnancy loss; we therefore used an indirect estimation approach to separate this total into complications of spontaneous and induced abortion.

We used available data on the biological pattern of all spontaneous abortions (unrelated to hospitalization), established by clinical studies, ${ }^{16}$ to indirectly estimate the number of Guatemalan women who have miscarriages at 13-22 weeks' gestation; these women are assumed to require care at a health facility. * Miscarriages at 13-22 weeks account for $2.9 \%$ of all recognized pregnancies, and live births for $84.8 \%$; therefore, such miscarriages are equal to $3.4 \%$ of all live births. The number of births in Guatemala in 2003 was estimated using age-specific fertility rates from the 2002 ENSMI and estimates of the number of women in each fiveyear age-group, nationally and for each region from the 2002 census, the most recent sources for these types of data. ${ }^{17}$ According to these calculations, an estimated 405,017 live 
TABLE 2. Measures of postabortion care and abortion morbidity, by facility ownership and region, 2003

\begin{tabular}{|c|c|c|c|c|c|c|c|c|c|c|c|}
\hline Measure & Total & Public & Private & $\begin{array}{l}\text { Metro- } \\
\text { politan }\end{array}$ & North & $\begin{array}{l}\text { North- } \\
\text { east }\end{array}$ & $\begin{array}{l}\text { South- } \\
\text { east }\end{array}$ & Central & $\begin{array}{l}\text { South- } \\
\text { west }\end{array}$ & $\begin{array}{l}\text { North- } \\
\text { west }\end{array}$ & Petén \\
\hline \multicolumn{12}{|l|}{ Availability of postabortion care } \\
\hline Total no. of facilities* & 183 & 56 & 127 & 51 & 9 & 28 & 9 & 20 & 43 & 13 & 10 \\
\hline $\begin{array}{l}\text { No. of beds in facilities per 100,000 } \\
\text { women aged 15-49 }\end{array}$ & 279 & 207 & 72 & 395 & 184 & 363 & 217 & 312 & 234 & 169 & 331 \\
\hline $\begin{array}{l}\% \text { of facilities offering only inpatient care } \\
\% \text { of facilities offering vacuum }\end{array}$ & 61 & 70 & 57 & 54 & 44 & 59 & 78 & 80 & 60 & 54 & 75 \\
\hline aspiration procedure $\ddagger$ & 30 & 54 & 20 & 27 & 25 & 30 & 11 & 35 & 34 & 39 & 38 \\
\hline \multicolumn{12}{|c|}{ Annual no. of abortion complications per facility§ } \\
\hline All facilities & 148 & 365 & 52 & 175 & 127 & 79 & 227 & 150 & 158 & 158 & 86 \\
\hline Public sector & 365 & na & na & 891 & 145 & 188 & 600 & 472 & 380 & 199 & 144 \\
\hline Private sector & 52 & na & na & 60 & 72 & 36 & 40 & 43 & 58 & 66 & 32 \\
\hline \multicolumn{12}{|l|}{$\begin{array}{l}\text { Annual abortion morbidity§ } \\
\text { All }\end{array}$} \\
\hline $\begin{array}{l}\text { No. of complications treated in } \\
\text { all facilities }\end{array}$ & 27,014 & 20,460 & 6,553 & 8,844 & 1,014 & 2,237 & 2,040 & 3,000 & 7,112 & 2,058 & 709 \\
\hline $\begin{array}{l}\text { Rate of complications treated in all } \\
\text { facilities per 1,000 women aged 15-49 } \\
\text { Induced }\end{array}$ & 9.9 & 7.5 & 2.4 & 12.6 & 4.6 & 9.8 & 9.4 & 10.2 & 11.2 & 6.0 & 9.0 \\
\hline $\begin{array}{l}\text { No. of complications treated in } \\
\text { all facilities } \\
\text { Rate of complications treated in all }\end{array}$ & 21,625 & $16,380^{* *}$ & $5,243^{* *}$ & 7,021 & 605 & 1,723 & 1,692 & 2,330 & 6,056 & 1,650 & 548 \\
\hline $\begin{array}{l}\text { Rate of complications treated in all } \\
\text { facilities per 1,000 women aged 15-49 }\end{array}$ & 8.0 & na & na & 10.0 & 2.7 & 7.6 & 7.8 & 7.9 & 9.6 & 4.8 & 7.0 \\
\hline Total no. of women aged 15-49 (in 000s) & 2,718 & na & na & 703 & 222 & 227 & 216 & 296 & 633 & 342 & 78 \\
\hline
\end{tabular}

*All facilities provide treatment for abortion complications. †One hundred and eight facilities offer only inpatient care, of which 52 are located in two regions ( 27 in the Metropolitan region and 25 in the Southwest). The number of facilities in different regions varies between four and 27 . \#Fifty-three facilities offer vacuum aspiration, of which 13 are located in the Metropolitan region and 14 in the Southwest. The number of facilities in different regions varies between one and 14 . §Includes spontaneous and induced abortion complications. ${ }^{* *}$ Assuming that public facilities treat $76 \%$ of abortion complication patients $(20,460 / 27,014=75.7 \%)$ and private facilities the remaining $24 \%(6,553 / 27,014=24.3 \%)$. Note: na=not applicable. Source: Total no. of women aged 15-49-reference 17.

births and 13,811 late spontaneous abortions occurred in 2003 in Guatemala.

A further adjustment was needed because only a certain proportion of women who need treatment for complications of late spontaneous abortion have access to a health facility. We assumed that this proportion was equivalent to the proportion of women giving birth who deliver in a hospital-39\% in Guatemala. ${ }^{* 18}$ We estimated that 5,389 women are treated in health facilities each year for complications of spontaneous abortion. ${ }^{\dagger}$ Therefore, 21,625 women are treated for complications of unsafe induced abortion each year in all public and private facilities.

- Number of induced abortions. To estimate the total number of abortions, we derived a national multiplier that represents the number of other induced abortions that occur for each woman who is hospitalized for treatment of induced abortion complications. This multiplier is a function of the degree of safety of abortion services and of access to hospital care. Where abortion services are safe and easily accessible, the multiplier is higher, because for every woman receiving treatment for unsafe induced abortion, there are many others who do not experience complications and so do not require or receive medical care. Likewise, the less safe and accessible abortion services are, the lower the multiplier, because more women have serious complications and require or receive treatment.

We derived the multiplier from information in the Health Professionals Survey. The reported proportions of women obtaining abortions according to type of provider were multiplied by the proportion who would be expected to experience complications, for each provider type. The resulting overall proportion of women having abortions who experience a serious complication was then multiplied by the proportion who are likely to obtain care from a hospital. Because conditions vary greatly by socioeconomic status and place of residence, these questions were asked separately about each of four subgroups of women: urban poor and nonpoor, and rural poor and nonpoor. The preceding calculations were done for each subgroup, producing the proportion expected to be hospitalized for abortion complications. These proportions were weighted by the relative sizes of the four groups nationally to arrive at a multiplier for the country as a whole.

Because direct experience in treating women with abortion complications may influence key informants' perceptions, we estimated the multiplier for different groups of respondents: physicians (i.e., those directly involved in clin-

*This proportion varied by region, and region-specific proportions were used in the calculations: $72 \%$ in the Metropolitan region, $25 \%$ in the North, $43 \%$ in the Northeast, $33 \%$ in the Southeast, $47 \%$ in the Central region, $31 \%$ in the Southwest, $20 \%$ in the Northwest and $31 \%$ in the Petén (source: reference 10)

†The number of women who are hospitalized was estimated to be 5,389 $(13,811 \times 39.02 \%)$. Information available on weeks of gestation of all postabortion patients from a study of 22 public hospitals (source: reference 3) was not used because these data are for both spontaneous and induced abortions, and because it is not known how representative the 22 facilities are of all 178 surveyed facilities that provide postabortion care in Guatemala. 


\begin{tabular}{|c|c|c|c|c|}
\hline \multirow[t]{2}{*}{ Region } & \multirow[t]{2}{*}{ No. of women treated } & \multicolumn{3}{|c|}{ Estimated no. of induced abortions } \\
\hline & & 2 & 3 & 4 \\
\hline Total & 21,625 & 43,349 & 64,974 & 86,599 \\
\hline Metropolitan & 7,021 & 14,073 & 21,094 & 28,114 \\
\hline North & 605 & 1,213 & 1,818 & 2,424 \\
\hline Northeast & 1,723 & 3,454 & 5,177 & 6,900 \\
\hline Southeast & 1,692 & 3,392 & 5,084 & 6,776 \\
\hline Central & 2,330 & 4,671 & 7,001 & 9,331 \\
\hline Southwest & 6,056 & 12,139 & 18,195 & 24,251 \\
\hline Northwest & 1,650 & 3,307 & 4,957 & 6,607 \\
\hline Petén & 548 & 1,099 & 1,647 & 2,196 \\
\hline
\end{tabular}

ical care) and those who are not physicians, and those who work primarily in the public sector (which receives the larger number of postabortion patients and the more severe cases) and those who work in the private sector. The results show that key informants who are physicians and those who work in the public sector perceive that the probability of medical complications is greater (resulting in lower multipliers) than do those who are not physicians and those who do not work in the public sector (multipliers of 2.47 and 2.26 vs. 3.00 and 3.13, respectively). ${ }^{19}$ Those who are directly involved in clinical care are likely to be influenced by the acute and severe postabortion complications they treat; as a result, they may overstate the degree to which abortion service provision is unsafe and their estimate of the multiplier is likely to be low. In contrast, those informants who are somewhat removed from direct postabortion care are likely to provide a more comprehensive, representative and accurate perspective on the overall abortion situation. Therefore, we based the estimates of abortion in Guatemala on the multiplier of 3, reflecting the responses of the latter group of respondents.

Given the assumptions underlying our estimates of the total number of abortions in Guatemala, we calculated a range of estimates using multipliers of 2, 3 and 4, nationally and for each region. The middle set of results is believed to be the most accurate estimate. Because the multiplier depends on both the degree of safety of abortion services

TABLE 4. Estimates of the abortion rate and the abortion ratio in 2003, by multiplier to account for women not treated in a hospital, according to region

\begin{tabular}{lccc|rrr} 
& \multicolumn{3}{l}{ Abortion rate } & \multicolumn{3}{c}{ Abortion ratio } \\
\cline { 2 - 7 } & \multicolumn{1}{c}{$\mathbf{2}$} & \multicolumn{1}{c}{3} & 4 & \multicolumn{1}{c}{2} & \multicolumn{1}{c}{3} & \multicolumn{1}{c}{4} \\
\hline Total & $\mathbf{1 6}$ & $\mathbf{2 4}$ & $\mathbf{3 2}$ & $\mathbf{1 1}$ & $\mathbf{1 6}$ & $\mathbf{2 1}$ \\
Metropolitan & 20 & 30 & 40 & 19 & 28 & 38 \\
North & 6 & 8 & 11 & 3 & 4 & 5 \\
Northeast & 15 & 23 & 30 & 10 & 15 & 20 \\
Southeast & 16 & 24 & 31 & 11 & 17 & 22 \\
Central & 16 & 24 & 32 & 11 & 17 & 23 \\
Southwest & 19 & 29 & 38 & 12 & 18 & 24 \\
Northwest & 10 & 15 & 19 & 6 & 8 & 11 \\
Petén & 14 & 21 & 28 & 7 & 11 & 14 \\
\hline
\end{tabular}

Notes: The abortion rate is the number of induced abortions per 1,000 women aged 15-49 per year. The abortion ratio is the number of induced abortions per 100 live births. and access to hospital care, the range of estimates for each region provides an indication of possible variation within regions based on their specific circumstances.

\section{Estimating Unintended Pregnancy}

To estimate numbers and rates of unintended pregnancy, we first calculated the number of unplanned births by applying the proportion of births that are unplanned (mistimed or unwanted at the time of conception, from the 2002 ENSMI) to the estimated total annual number of live births. Combining this number with the number of induced abortions yielded an estimate of the number of unintended pregnancies for 2003. We then calculated the rate of unintended pregnancies per 1,000 women of reproductive age and the proportion of pregnancies that were unintended.

\section{Measuring Contraceptive Use and Unmet Need}

We obtained the proportion of women using contraceptives from the 1995 DHS and the 2002 ENSMI. We look separately at modern methods (male and female sterilization, IUDs, pills, injectables, implants, condoms and spermicides) and traditional methods (periodic abstinence, withdrawal and country-specific methods, including lactational amenorrhea when it is mentioned). We present data for women who are married (legally or consensually) and for women who are unmarried but currently sexually active (defined as having had intercourse in the past three months). Using these two surveys, we also estimate unmet need for contraceptives among married women aged 15-49.

\section{RESULTS}

\section{Provision of Postabortion Care}

The 183 health facilities that treat postabortion complications are unevenly distributed across the country, being concentrated in the Southwest and Metropolitan regions (43 and 51 facilities, respectively-Table 2, page 139). The ratio of facilities per 100,000 women aged 15-49 also varies substantially across regions: The Northeast and Petén regions have 12-13 facilities per 100,000 women, whereas the ratio is much lower in the Metropolitan, Central and Southwest regions (seven facilities per 100,000), and even lower in the remaining three regions (four per 100,000). However, regions ranked differently on a more exact measure of availability of postabortion services, the number of beds per 100,000 women: The Metropolitan region has the best availability (395 beds per 100,000), followed by the Northeast, Central and Petén regions (312-363 beds per 100,000). The other four regions have poorer availability (169-234 beds per 100,000). The average annual number of abortion patients treated per site is highest in the Southeast region (227), somewhat lower in five regions (127-175), and much lower in the Northeast and Petén (79-86).

Of the 183 facilities that offer postabortion care, 69\% are in the private sector and $31 \%$ are in the public sector (not shown). Although private facilities outnumber public facilities, the annual caseload of abortion complications per facility is seven times as high in public facilities as in private 
ones ( 365 vs. 52 patients). The public sector treats $76 \%$ of all postabortion patients, and has $74 \%$ of all hospital beds. Six in 10 of all facilities provide only inpatient postabortion care; most of the others provide both inpatient and outpatient care. Nearly a third of all facilities offer the vacuum aspiration procedure, but half of public facilities do so, compared with only a fifth of private facilities. Almost all facilities use the D\&C (dilation and curettage) procedure.

\section{Abortion Morbidity}

A total of 27,014 women of reproductive age received postabortion care (including treatment for both spontaneous and induced abortions) in health facilities in Guatemala in 2003. Nationally, the annual rate of abortion complications treated at formal health facilities was 10 per 1,000 women; the rate was higher in the Metropolitan region (13 per 1,000), much lower in the North and Northwest (5-6 per 1,000), and moderate in the five remaining regions $(9-11$ per 1,000$)$.

Subtracting the estimated number of women treated for spontaneous abortion complications from the total number treated leaves 21,625 women who were treated for complications from induced abortions. This means that eight out of every 1,000 women of reproductive age were hospitalized for complications of unsafe abortions each year. Morbidity from unsafe abortion treated at health facilities was somewhat higher than average in the Metropolitan and Southwest regions (10 per 1,000 women), about average in the Northeast, Southeast, Central and Petén regions, and lower than average in the North and Northwest regions (3-5 per 1,000).

According to the Health Professionals Survey, about twothirds of abortions among relatively well-off urban women are performed by trained health professionals, such as physicians, nurses or midwives (not shown); however, only about four in 10 abortions among nonpoor women in rural areas are thought to be performed by professionals, and about the same proportion are done by less safe providers, particularly traditional birth attendants or comadronas tradicionales. ${ }^{20}$ Poor women (living in either urban or rural areas) and indigenous women have a similar distribution according to type of abortion provider.* These disadvantaged groups are considered to obtain abortions primarily from birth attendants (49-63\%), with only 15\% or fewer going to each of the two categories of more highly trained providers (physicians and trained nurses or midwives); small proportions of these women go to pharmacists or self-induce. However, complications may result from procedures carried out by trained providers who have little experience or who work in unhygienic settings. In addition, a substantial proportion of abortions in all subgroups of women entail a high risk of complications because they are carried out by untrained providers (traditional healers, lay practitioners, pharmacists or the women themselves).

*Fifty-four percent of Guatemala's people live in rural areas, and $41 \%$ are indigenous (source: reference 17).

\section{Abortion Incidence}

Almost 65,000 induced abortions are estimated to have occurred in Guatemala in 2003 (Table 3). This is the medium estimate in a range that extends from 43,000 to 87,000 (using multipliers of 2, 3 and 4). The medium estimate indicates that, on average, one woman is hospitalized for every three who obtain induced abortions. We consider this estimate to be the best approximation of the number of induced abortions.

The estimated national abortion rate in 2003 is 24 induced abortions per 1,000 women aged 15-49 (based on the medium multiplier of 3-Table 4); the low estimate is 16 per 1,000 and the high estimate is 32 per 1,000 (based on multipliers of 2 and 4, respectively). Rates are higher than average in the Metropolitan and Southwest regions (29-30 per 1,000, based on a multiplier of 3), followed by the Northeast, Southeast, Central and Petén regions (21-24 per 1,000). The North and Northwest regions have substantially lower rates (8-15 per 1,000).

The abortion ratio is estimated to fall between 11 and 21 abortions per 100 live births, with a medium value of 16 per 100 births. This means that in Guatemala as a whole and in four regions with average rates (Northeast, Southeast, Central and Southwest), about one pregnancy is interrupted by an induced abortion for every six that result in a birth. In the Metropolitan region, however, there is one induced abortion for every four births. The lowest abortion ratios are found in the North, Northwest and Petén regions, where about one or fewer abortions occur for every 10 births.

\section{Abortion in the Context of Unintended Pregnancy}

To understand the context in which induced abortion occurs in Guatemala, it is important to examine the planning status of recent births. Although the overall proportion of unplanned births (mistimed or unwanted at the time of conception) has remained the same from 1995 to 2002 (28-29\%-Table 5), rates have increased by $15-16 \%$ in three regions (North, Central and Southwest), and decreased by $13 \%$ and $27 \%$ in two regions (Southeast and Metropolitan, respectively).

Each year, an estimated 557,000 pregnancies occur in

\begin{tabular}{|c|c|c|c|c|c|c|}
\hline \multirow[t]{2}{*}{ Region } & \multicolumn{2}{|c|}{ Unwanted } & \multicolumn{2}{|c|}{ Mistimed } & \multicolumn{2}{|c|}{ Unplanned } \\
\hline & 1995 & 2002 & 1995 & 2002 & 1995 & 2002 \\
\hline Total & 11 & 14 & 18 & 14 & 29 & 28 \\
\hline Metropolitan & 15 & 11 & 22 & 16 & 37 & 27 \\
\hline North & 12 & 16 & 15 & 16 & 27 & 32 \\
\hline Northeast & 15 & 17 & 16 & 13 & 31 & 30 \\
\hline Southeast & 15 & 16 & 21 & 16 & 36 & 32 \\
\hline Central & 9 & 15 & 21 & 21 & 30 & 36 \\
\hline Southwest & 8 & 14 & 15 & 13 & 23 & 27 \\
\hline Northwest & 7 & 10 & 12 & 8 & 19 & 18 \\
\hline Petén & na & 19 & na & 9 & na & 29 \\
\hline
\end{tabular}

Notes: Unplanned births are the sum of unwanted and mistimed births. Percentages are based on live births in the five years before interview. The Petén region was not included in the 1995 DHS. na=not available. 
TABLE 6. Estimates of number of pregnancies, unintended pregnancy rate, percentage of pregnancies that were unintended and pregnancy rate, according to region, 2003

\begin{tabular}{lcllc} 
Region & $\begin{array}{l}\text { No. of } \\
\text { pregnancies }\end{array}$ & $\begin{array}{l}\text { Unintended } \\
\text { pregnancy rate* }\end{array}$ & $\begin{array}{l}\text { \% of pregnancies that } \\
\text { were unintended }\end{array}$ & $\begin{array}{l}\text { Pregnancy } \\
\text { rate† }\end{array}$ \\
\hline Total & $\mathbf{5 5 7 , 4 9 2}$ & $\mathbf{6 6}$ & $\mathbf{3 2}$ & $\mathbf{2 0 5}$ \\
Metropolitan & 112,451 & 59 & 37 & 160 \\
North & 58,640 & 77 & 29 & 264 \\
Northeast & 48,258 & 70 & 33 & 212 \\
Southeast & 42,353 & 68 & 35 & 196 \\
Central & 57,546 & 75 & 38 & 195 \\
Southwest & 141,093 & 72 & 32 & 223 \\
Northwest & 76,916 & 46 & 21 & 225 \\
Petén & 20,234 & 77 & 30 & 258
\end{tabular}

*Number of unintended pregnancies (unplanned births + abortions) per 1,000 women aged 15-49 per year. tNumber of pregnancies (live births + induced abortions + spontaneous abortions) per 1,000 women aged 15-49 per year. Spontaneous pregnancy loss was estimated using a formula based on the biological pattern of pregnancy loss: $10 \%$ of abortions and $20 \%$ of live births. Notes: Age-specific fertility rates and the planning status of births obtained from the 2002 ENSMI were assumed to apply to 2003; population estimates for 2003 were based on the 2002 census.
Guatemala (Table 6); 12\% end as induced abortions, 16\% as spontaneous abortions and the remaining $72 \%$ as births (not shown). The wide range in number of pregnancies among regions reflects variations in both population sizes and pregnancy rates.

Nationally, 66 unintended pregnancies occurred per 1,000 women in 2003, and one-third of all pregnancies were unintended. All but two regions had higher-than-average unintended pregnancy rates (68-77 per 1,000). The Northwest region had a noticeably lower than average unintended pregnancy rate (46 per 1,000), as well as the lowest proportion of unintended pregnancies (21\%). The Metropolitan region had a somewhat lower than average unintended pregnancy rate (59 per 1,000), but a higher-than-average percentage of unintended pregnancies (37\%), presumably reflecting both its higher levels of contraceptive use and its more educated population, which is likely to be more motivated to achieve fertility preferences.

Overall, 205 pregnancies occurred per 1,000 women aged 15-49 in 2003. The pregnancy rate varied substantially across regions, being lowest in the Metropolitan region ( 160 per 1,000) and highest in the Petén and North regions (258 and 264 per 1,000, respectively).

\section{DISCUSSION}

The abortion rate in Guatemala-24 per 1,000 women of reproductive age-is similar to the $\mathrm{WHO}$ estimated rate for Central America. ${ }^{21}$ However, although the overall rate in Guatemala is substantially lower than that of Latin America in 2000 (34 per 1,000 women), ${ }^{22}$ the two most populous regions of the country-the Metropolitan and Southwest regions-have abortion rates closer to the WHO Latin America regional estimate for 2000 and to rates that prevailed in some Latin American countries around 1990. ${ }^{23}$

Several decades ago, the conditions of abortion provision in Latin America were considered to be very unsafe: A 1965 Chilean study estimated that one in three abortions resulted in serious complications that required hospitalization. ${ }^{24}$ The same level of risk was estimated for Guatemala in 2003, suggesting that abortion provision in this country is also very unsafe, more so than in other Latin American nations in recent years: Estimates for six countries in the early 1990s found that about one in five abortions resulted in a complication that was treated at a hospital. ${ }^{25}$ Further evidence of unsafe abortion services in Guatemala is the high annual rate of hospitalization for complications (eight per 1,000 women). The burden of postabortion care falls primarily on the public sector, which treated three in four of the almost 22,000 women who were hospitalized with induced abortion complications in 2003.

Demographic factors-particularly preferences for family size and timing of births, as well as contraceptive use patterns-may explain the variation in abortion rates across the country. The Metropolitan region, which has a higherthan-average abortion rate (30 per 1,000), also has the highest rate of contraceptive use (60\%), the lowest rate of unmet need for contraceptives (18\%), and a small gap between actual and wanted family size (3.2 vs. 2.8). ${ }^{26}$ This region also has a lower-than-average unintended pregnancy rate, but a higher-than-average proportion of unintended pregnancies that end in abortion ( $51 \%$ vs. $10-40 \%$ in other regions). Education could be a factor in this elevated rate, because the more educated a woman is, the higher her motivation to terminate an unintended pregnancy and the greater her access to services. In the Metropolitan region, $52 \%$ of women aged 15-49 have secondary or higher education, whereas this proportion in the other regions is $21 \%$ or lower. ${ }^{27}$ In the Southwest region, where the abortion rate is also higher than average (29 per 1,000), other likely factors are found: Contraceptive use is lower than average (36\%), the proportion of women with unmet need is among the highest in the country (34\%), and the gap between actual and wanted family size ( 5.0 vs. 4.2 ) is wider than in the Metropolitan region. In the North and Northwest regions, both actual and desired fertility rates are much higher than the average; abortion rates are low (eight and 15 per 1,000 women, respectively), as is contraceptive use (32\% and $27 \%$, respectively). ${ }^{28}$

Nationally, women are having smaller families, which declined from an average of 5.6 children in 1987 to 4.4 children in 2002. ${ }^{29}$ At the same time, desired family size also declined, from 4.9 to 3.7, and the gap between the number of children women are actually having and the number they want continues to be substantial. The estimated number of pregnancies ending in abortion (one in eight) and the high level of unintended pregnancy (32\%) indicate that unmet need for contraceptive services in Guatemala is likely to be high. Other evidence indicates that unmet need for effective contraception in all regions of the country increased between 1987 and 2002. In 1987, about one in five married women aged 15-49 did not want a child soon or at all but were not using a contraceptive method (19\%); this proportion increased to $24 \%$ in 1995 and $28 \%$ in $2002 .{ }^{30}$ In the Metropolitan and Central regions, unmet need increased by $20 \%$ or less over the same period, but in the remaining regions it increased by $36-45 \%$. 
The relatively low use of contraceptives in Guatemala may be attributed to a number of factors: lack of knowledge of birth control methods and of sources for services, and barriers related to ethnicity, poverty and access to health services. In 2002, 45\% of all women did not know of any contraceptive method. ${ }^{* 31}$ The lack of knowledge was higher in rural areas (56\%), among indigenous women (66\%), and in the Northwest, North and Southwest regions (78\%, $57 \%$ and $52 \%$, respectively). These high levels of inadequate knowledge are likely related to the government's longstanding resistance to providing family planning in public health facilities. ${ }^{32}$ Although the government recently approved a family planning law that guarantees universal, equitable access to voluntary family planning methods and adequate sex education, there is still strong opposition from religious and conservative groups to implementation of the law. 33

Extreme poverty is another barrier that makes access to contraceptives and health facilities more difficult. More than half of Guatemalan families live below the poverty line (56\%, including 16\% who cannot afford a basic basket of food), and poverty is even higher in the indigenous population ( $76 \%$ and $27 \%$, respectively). ${ }^{34}$ In addition, public health facilities tend to be underutilized due to the poor quality of services. People who can afford to often prefer to use private facilities, and the poorest frequently rely on care from members of their household or on self-medication. ${ }^{35}$ Considering that $41 \%$ of the Guatemalan population is of Mayan descent, family planning education campaigns should take into account Mayan values and beliefs. Furthermore, since Guatemala is still a predominantly rural country (54\% of its people live in rural areas), there is a great need to improve the availability of and access to contraceptive services, as well as the quality of services in these areas.

\section{Limitations}

Documenting the incidence of abortion is very difficult in countries where abortion is highly restricted by law and where official data may not exist or may be incomplete. Researchers have developed indirect estimation methodologies in response to the need for such estimates. ${ }^{36}$ Although the present methodology has been widely used and tested in several countries over the past 15 years, it relies on a number of assumptions, as outlined earlier. Because women often underreport their use of abortion services, we rely on the perceptions of health professionals who are knowledgeable about abortion service provision to estimate the proportion of all women having abortions who will be hospitalized for treatment of complications. We selected key informants who have a broad range of experience and who are familiar with the context of abortion in rural and urban areas; information was obtained on differences according to poverty level and ethnicity to improve the estimates.

We also depend on senior hospital officials to estimate

*The 2002 ENSMI reported that $92 \%$ of all women were aware of at least one method; this difference is likely due to interviewer probing for each specific method. the number of women treated at their facility for postabortion complications in the past month and in an average month. Their estimates are likely to be approximate, but are unlikely to be biased overall. Comparison with a surveillance program in 22 public hospitals provides some support for this study's estimates of the number of women treated for postabortion complications. ${ }^{37}$ The surveillance program covered an 18-month period (July 2003 to December 2004), while our estimate was for the 12 months of 2003. After adjustments to have a comparable 12-month period, the number of incomplete abortions reported in our study was similar-only 17\% higher than the number reported in the surveillance study. Several factors might explain this difference. The surveillance program extracted information from medical records on patients who had been diagnosed as having or probably having an incomplete abortion, whereas we asked key informants at each hospital to estimate the number of inpatients and outpatients treated for abortion complications. Furthermore, the different calendar periods covered may result in some differences in number of patients. In addition, despite efforts to minimize underregistration in the surveillance study, some cases may have been missed, particularly outpatients. In contrast, our facilities survey specifically asked about postabortion treatment provided on an outpatient basis.

\section{Conclusions}

New estimates of the incidence of unintended pregnancy in Guatemala should help to raise awareness among policymakers and program managers of the difficulty that women and couples are having in planning pregnancies and births. These estimates highlight the inadequate access to contraceptive information and services. The increase between 1987 and 2002 in the proportion of married women who have an unmet need for contraception further indicates that provision of family planning services is falling increasingly behind the demand as the motivation to have smaller families continues to grow. National and regional estimates of the incidence of abortion and abortion morbidity, now available for the first time, provide evidence that unsafe abortion is occurring in all parts of the country and is having a substantial impact on women's health.

There is a critical need for a comprehensive and coordinated effort to assist the large numbers of women who want smaller families and want to space births, but who are not practicing contraception and are therefore at high risk of unintended pregnancy and unsafe abortion. The variation in fertility preferences across regions, as well as in the incidence of unintended pregnancy and abortion, suggests that informed and innovative policies and programs are needed. Governmental responses must also address the special needs of poor, rural and indigenous women and couples.

\section{REFERENCES}

1. Guatemala Penal Code Decree No. 17-73, Articles 133 and 137, 1999.

2. Figueroa W and Schieber B, Study of the Use of Financial Resources in Reproductive Health and Postabortion Care, New York: Population Council, 2001. 
3. Ministerio de Salud Pública y Asistencia Social (MSPAS) and Centro de Investigación Epidemiológica en Salud Sexual y Reproductiva (CIESAR), Expansión de la atención postaborto en 22 hospitales departamentales de Guatemala: 18 meses de resultados, Boletín del Programa Nacional de Atención Postaborto, 2005, Vol. 1, No. 4; and Kestler E et al., Scaling up post-abortion care in Guatemala: initial successes at national level, Reproductive Health Matters, 2006, No. 27, pp. 138-147.

4. Grajeda R et al., Estudio multicentro sobre el aborto, Guatemala City, Guatemala: World Health Organization (WHO), 1995.

5. Figueroa W and Schieber B, 2001, op. cit. (see reference 2).

6. Ibid., p. 12.

7. MSPAS, Informe Final: Línea Basal de Mortalidad Materna para el Año 2000, Guatemala City, Guatemala: MSPAS, 2003

8. Kestler E and Ramírez L, Pregnancy-related mortality in Guatemala, 1993-1996, Pan American Journal of Public Health, 2000, 7(1):41-46.

9. The Alan Guttmacher Institute (AGI), Sharing Responsibility: Women, Society and Abortion Worldwide, New York: AGI, 1999, p. 42.

10. MSPAS et al., Encuesta Nacional de Salud Materno Infantil (ENSMI) 2002, Guatemala City, Guatemala: MSPAS, 2003.

11. United Nations (UN) Population Division, World contraceptive use, 2003, wall chart, New York: UN, 2004.

12. Ley de Desarrollo Social, Artículo 26, No. 5, Guatemala City, Guatemala, 2001; Secretaría de Planificación y Programación de la Presidencia (SEGEPLAN), Política de Desarrollo Social y Población, Guatemala City, Guatemala: SEGEPLAN, 2002; and Secretaría Presidencial de la Mujer, Política Nacional de Promoción y Desarrollo de las Mujeres Guatemaltecas y Plan de Equidad de Oportunidades, 2001-2006, Guatemala City, Guatemala, 2001.

13. Singh $S$ and Wulf D, Estimated levels of induced abortion in six Latin American countries, International Family Planning Perspectives, 1994, 20(1):4-13; and Singh S et al., The incidence of induced abortion in Uganda, International Family Planning Perspectives, 2005, 31(4):183-191

14. Kestler E and Ramírez L, Informe técnico parcial, unpublished document, Guatemala City, Guatemala: CIESAR, 2004.

15. Henshaw SK et al., The incidence of induced abortion in Nigeria, International Family Planning Perspectives, 1998, 24(4):156-164; Singh $S$ et al., Estimating the level of abortion in the Philippines and Bangladesh, International Family Planning Perspectives, 1997, 23(3): 100-107; Juarez F et al., The incidence of induced abortion in the Philippines: current level and recent trends, International Family Planning Perspectives, 2005, 31(3):140-149; and Singh S and Wulf D, 1994, op. cit. (see reference 13)

16. Bongaarts J and Potter RG, Fertility, Biology and Behavior: An Analysis of the Proximate Determinants, New York: Academic Press, 1983, p. 39 and Harlap S, Shiono PH and Ramcharan S, A life table of spontaneous abortions and the effects of age, parity and other variables, in: Hook EB and Porter I, eds., Human Embryonic and Fetal Death, New York: Academic Press, 1980, Table 1, pp. 148 \& 157.

17. Instituto Nacional de Estadística, Censo 2002: XI de Población y VI de Habitación, <http://www.ine.gob.gt/content/consul_2/pob/ censo2002.pdf>, accessed Aug. 11, 2006.

18. MSPAS et al., 2003, op. cit. (see reference 10).

19. Prada E et al., Abortion and postabortion care in Guatemala, a report from health care professionals and health facility survey, Occasional Report, New York: AGI, 2005, No. 18, Table 4.4.

20. Ibid.

21. WHO, Unsafe Abortion, Global and Regional Estimates of the Incidence of Unsafe Abortion and Associated Mortality in 2000, fourth ed., Geneva: WHO, 2004.

22. Ibid.

23. Singh S and Wulf D, 1994, op. cit. (see reference 13)

24. Armijo R and Monreal T, Epidemiology of provoked abortion in Santiago, Chile, in: Muramatsu M and Harper PA, eds., Population Dynamics: International Action and Training Programs, Baltimore, MD, USA: Johns Hopkins University Press, 1965, pp. 137-160.

25. Ferrando D, Prevalencia del aborto inducido en el Peru, Lima, Peru: Pathfinder International and Flora Tristan, 2001; and Singh S and Wulf D, 1994, op. cit. (see reference 13).
26. MSPAS et al., 2003, op. cit. (see reference 10)

27. Ibid.

28. Ibid.

29. MSPAS, Instituto de Nutrición de Centro América y Panamá (INCAP) and Institute for Resource Development (IRD)/Westinghouse, Encuesta Nacional de Salud Materno Infantil (ENSMI) 1987, Columbia, MD, USA: IRD/Westinghouse, 1989; and MSPAS et al., 2003, op. cit. (see reference 10).

30. MSPAS, INCAP and IRD/Westinghouse, 1989, op. cit. (see reference 29); MSPAS et al., Encuesta Nacional de Salud Materno Infantil (ENSMI) 1995, Guatemala City, Guatemala: MSPAS, 1996; and MSPAS et al., 2003, op. cit. (see reference 10).

31. Gragnolati M and Marini A, Health and Poverty in Guatemala, Policy Research, Working Paper, Washington, DC: World Bank, 2003, No. 2966, p. 9.

32. Hall MK and Scott JB, An Unfulfilled Human Right: Family Planning in Guatemala, New York: Center for Reproductive Law and Policy, 2003.

33. Pérez S, La Corta de Constitucionalidad deja vigente Ley de Planificacíon, Prensa Libre, June 7, 2006, <http://www.prensalibre. com/pl/2006/junio/07/143603.html>, accessed Aug. 7, 2006.

34. Gragnolati M and Marini A, 2003, op. cit. (see reference 31).

35. Ibid.

36. Rossier C, Estimating induced abortion rates: a review, Studies in Family Planning, 2003, 34(2):87-102.

37. MSPAS and CIESAR, 2005, op. cit. (see reference 3).

\section{RESUMEN}

Contexto: Si bien la ley guatemalteca sólo permite la práctica del aborto inducido para salvar la vida de la mujer, muchas mujeres con embarazos no planeados se someten a abortos, con frecuencia en condiciones de riesgo. Aunque no existen datos a nivel nacional sobre la incidencia de este procedimiento, estudios recientes indican que los abortos practicados en condiciones de riesgo son un factor clave que contribuye a la morbilidad y mortalidad materna en ese país.

Métodos: En 2003 se realizaron encuestas en todos los hospitales que tratan mujeres con complicaciones postaborto y a 74 profesionales que tienen conocimientos acerca de las condiciones en que se practican los abortos en Guatemala. Se utilizaron técnicas indirectas de estimación para calcular el número de abortos inducidos realizados anualmente. Se calcularon las tasas y razones de abortos, y el nivel de embarazos no planeados correspondientes a todo el país y a cada una de sus ocho regiones. Resultados: En Guatemala, se realizan casi 65.000 abortos inducidos por año y aproximadamente 21.600 mujeres son hospitalizadas para tratamiento de complicaciones postaborto. Se realizan 24 abortos por cada 1.000 mujeres de 15-49 años de edad, y ocurre un aborto por cada seis nacimientos. La tasa de abortos es más elevada que el promedio en la región Sur-Occidente (una región relativamente menos desarrollada, cuya población es en su mayoría indígena) y en la región Metropolitana (la región más urbanizada, con una población en su mayoría no indígena) (29-30 por cada 1.000 mujeres). Más de la cuarta parte de todos los nacimientos no son planeados; al combinar los nacimientos no planeados con los abortos inducidos se concluye que aproximadamente el 32\% de los embarazos en Guatemala no son planeados, y la tasa de embarazos no planeados es de 66 por cada 1.000 mujeres. 
Conclusiones: El aborto practicado en condiciones de riesgo tiene un impacto significativo en la salud de la mujer en Guatemala. Es necesario contar con programas gubernamentales integrales, los cuales prestan particular atención en las diferencias regionales, para abordar el embarazo no planeado y el aborto en condiciones de riesgo.

\section{RÉSUMÉ}

Contexte: Malgré la restriction de la législation guatémaltèque sur l'avortement aux seuls cas où la vie de la femme est en danger, beaucoup de femmes se font avorter, dans des conditions souvent non médicalisées et en réponse à une grossesse non planifiée. De récentes études indiquent que l'avortement non médicalisé constitue un facteur clé de morbidité et mortalité maternelle dans le pays. Il n'existe cependant pas de données nationales sur l'incidence de l'avortement.

Méthodes: Une étude de tous les hôpitaux traitant les complications de l'avortement et une enquête auprès de 74 professionnels au courant des conditions de l'avortement au Guatemala ont été menées en 2003. Les techniques d'estimation indirecte ont permis de calculer le nombre d'avortements pratiqués chaque année. Le taux et rapport d'avortement et le taux de grossesse non planifiée ont été calculés pour le pays et ses huit régions.

Résultats: Près de 65.000 avortements sont pratiqués chaque année au Guatemala et quelque 21.600 femmes sont hospitalisées pour le traitement de complications. L'avortement se pra- tique à un taux de 24 pour mille fermmes âgées de 15 à 49 ans; l'avortement se calcule à un pour six naissances. Le taux d'avortement est supérieur à la moyenne dans le sud-ouest (moins développé, abritant principalement une population indigène) et dans les régions métropolitaines (plus développées, habitées surtout par les populations non indigènes) (29-30 pour mille femmes). Plus de $25 \%$ des naissances ne sont pas planifiées. La combinaison des naissances non planifiées et des avortements donne à penser que 32\% des grossesses survenant au Guatemala ne sont pas planifiées, soit un taux de grossesse non planifiée de 66 pour mille femmes.

Conclusions: L'avortement non médicalisé produit un impact significatif sur la santé des femmes au Guatemala. Il serait nécessaire d'entreprendre des programmes d'État globaux visant les problèmes de grossesse non planifiée et de l'avortement non médicalisé et tenant compte des différences régionales.

\section{Acknowledgments}

This research was supported by the Netherlands Ministry for Development Cooperation, the World Bank and the United Kingdom's Department for International Development. The authors thank the fieldwork team of three regional coordinators and 12 interviewers for their invaluable contribution in carrying out the surveys. They also thank Emily Stone, Lindsay Dauphinee and Caroline Sten for research support, and Akinrinola Bankole and Lisa Remez for their insightful comments on earlier versions of this article. The findings and conclusions expressed are entirely those of the authors.

Author contact:ssingh@guttmacher.org 